\title{
STOCK EXCHANGES PURSUANT TO CORPORATE CONSOLIDATION : A SECTION 16(b) "PURCHASE OR SALE"?
}

Section 16(b) of the Securities Exchange Act of $1934^{1}$ is designed to curb short-swing speculative trading in the equity securities of publicly held corporations by insiders whose position gives them access to information not available to the investing public and the ability to influence the policies taken by their corporations. It operates by allowing the issuer of securities registered under section 12 of the Act, ${ }^{2}$ or a stockholder suing on its behalf, to recover any "profit realized" by corporate "insiders" on purchases and sales (or sales and purchases) ${ }^{3}$ of the issuer's stock within any period of less than six months. ${ }^{4}$ It is no defense that the insider entered into the transaction for legitimate

\section{U.S.C. $\$ 78 p$ (b) (1964).}

For the purpose of preventing the unfair use of information which may have been obtained by such beneficial owner, director, or officer by reason of his relationship to the issuer, any profit realized by him from any purchase and sale, or any sale and purchase, of any equity security of such issuer (other than an exempted security) within any period of less than six months, unless such security was acquired in good faith in connection with a debt previously contracted, shall inure to and be recoverable by the issuer, irrespective of any intention on the part of such beneficial owner, director, or officer in entering into such transaction of holding the security purchased or of not repurchasing the security sold for a period exceeding six months. Suit to recover such profit may be instituted at law or in equity in any court of competent jurisdiction by the issuer, or by the owner of any security of the issuer in the name and in behalf of the issuer if the issuer shall fail or refuse to bring such suit within sixty days after request or shall fail diligently to prosecute the same thereafter; but no such suit shall be brought more than two years after the date such profit was realized. This subsection shall not be construed to cover any transaction where such beneficial owner was not such both at the time of the purchase and sale, or the sale and purchase, of the security involved, or any transaction or transactions which the Commission by rules and regulations may exempt as not comprehended within the purpose of this subsection.

215 U.S.C. $\$ 78 l$ (1964). Briefly, the securities covered by this section include all those traded on a national securities exchange, and those securities the issuer of which has total assets exceeding $\$ 1,000,000$ and a class of equity securities held of record by 500 or more persons. The extension of these provisions to the large overthe-counter companies was made by Congress in the 1964 Securities Acts Amendments. See SEC Securities Exchange Act Release No. 7425 (Sept. 15, 1964).

3 For purposes of the section, a sale at 100 followed by a purchase at 75 constitutes the same "profit" as a purchase at 75 followed by a sale at 100 .

4 The "insiders" to whom the section is applicable are defined in section $16(a)$, 15 U.S.C. $\$ 78$ p (a) (1964) :

Every person who is directly or indirectly the beneficial owner of more than 10 per centum of any class of any equity security (other than an exempted security) which is registered pursuant to section 12 of this title, or who is a director or an officer of the issuer of such security. . . . 
reasons or did not actually make use of inside information. ${ }^{5}$ By providing for the removal of profits from such transactions, it is felt that short-swing speculation will be deterred.

The recent boom in corporate merger activities presents once again one of the stubborn problems raised by the provisions of this section: the definition of "purchase and sale." The question presented is whether shares acquired or disposed of in an exchange pursuant to a merger or other similar acquisition transaction should be considered to have been "purchased" or "sold" within the meaning of section 16(b). The definitions of these terms are found in the general definitional section of the Act. "[U]nless the context otherwise requires" the term " 'purchase' . . . include[s] any contract to buy, purchase or otherwise acquire"; ${ }^{6}$ the term "sale" ... include[s] any contract to sell or otherwise dispose of." 7 While everyday transactions through a broker are clearly included within these broad definitions, the status of less ordinary, "unorthodox," 8 acquisitions and dispositions has often been uncertain. A large amount of litigation has arisen involving the receipt and exercise of warrants and options to purchase stock, ${ }^{9}$ gifts of stock, ${ }^{10}$ and the conversion of convertible securities. ${ }^{11}$ Although the few cases involving mergers and other corporate acquisitions have almost uniformly held section $16(\mathrm{~b})$ applicable, ${ }^{12}$ it is not at all clear that the purposes of the section would be promoted by its automatic application to all such exchanges. The problem has often been recognized, but too few cases have been decided for the emergence of a

5 E.g., Western Auto Supply Co. v. Gambel-Skogmo, Inc., 348 F.2d 736 (8th Cir. 1965) ; Magida v. Continental Can Co., 231 F.2d 843 (2d Cir.), cert. denied, 351 U.S. 972 (1956); Smolowe v. Delendo Corp., 136 F.2d 231 (2d Cir.), cert. denied, 320 U.S. 751 (1943) ; Jefferson Lake Sulfur Co. v. Walet, 104 F. Supp. 20, 23-24 (E.D. La. 1952), aff'd, 202 F.2d 433 (5th Cir.), cert. denied, 346 U.S. 820 (1953).

- Securities Exchange Act of 1934, §3(a) (13), 15 U.S.C. $\$ 78 c(a)(13)$ (1964).

7 Id., §3 (a) (14), 15 U.S.C. \& 78c(a) (14) (1964).

8 As described in 2 L. Loss, Securities Regulation 1069 (2d ed. 1961) [hereinafter cited as Loss].

${ }^{9}$ E.g., Blau v. Ogsbury, 210 F.2d 426 (2d Cir. 1954); Pellegrino v. Nesbitt, 203 F.2d 463 "' (9th Cir. 1953); Walet v. Jefferson Lake Sulphur Co., 202 F.2d 433 (5th Cir.), cert. denied, 346 U.S. 820 (1953); Shaw v. Dreyfus, 172 F.2d 140 (2d Cir.), cert. denied, 337 U.S. 907 (1949); Greene v. Dietz, 143 F. Supp. 464 (S.D.N.Y. 1956), aff'd, 247 F.2d 689 (3d Cir. 1957) ; Truncale v. Blumberg, 80 F. Supp. 387 (S.D.N.Y. 1948), aff'd, per curiam sib nom. Truncale v. Scully, 182 F.2d 1021 (2d Cir. 1950).

10 E.g., Shaw v. Dreyfus, 172 F.2d 140 (2d Cir.), cert. denied, 337 U.S. 907 (1949); Truncale v. Blumberg, 80 F. Supp. 387 (S.D.N.Y. 1948), aff'd per curiam sub nom. Truncale v. Scully, 182 F.2d 1021 (2d Cir. 1950).

11 E.g., Petteys v. Butler, 367 F.2d 528 (8th Cir. 1966), cert. denied, 385 U.S. 1006 (1967) ; Blau v. Lamb, 363 F.2d 507 (2d Cir. 1966), cert. denied, 385 U.S. 1002 (1967) ; Heli-Coil Corp. v. Webster, 352 F.2d 156 (3d Cir. 1965); Blau v. Max Factor \& Co., 342 F.2d 304 (9th Cir.), cert. denied, 382 U.S. 892 (1965); Ferraiolo v. Newman, 259 F.2d 342 (6th Cir. 1958), cert. denied, 359 U.S. 927 (1959) ; Park \& Tilford, Inc. v. Schulte, 160 F.2d 984 (2d Cir.), cert. denied, 332 U.S. 761 (1947).

12 See cases cited notes $63,65,67,68,71,75 \& 106$ supra. 
comprehensive doctrine. ${ }^{13}$ This Comment will analyze the factors which should determine the applicability of section $16(\mathrm{~b})$ to such transactions and suggest an approach which will minimize the potential "overkill" of the section while still fulfilling its purposes.

\section{The Law of "Purchase and Sale" and the "SubJective" and “ObJective" Tests}

Two different approaches have been developed by the courts in attempting to apply the terms "purchase" and "sale" to some of the "unorthodox" exchanges of securities. Variously described as the "subjective" or "pragmatic" and the "objective" or "per se" test, ${ }^{14}$ they represent conflicting views as to how the purposes of the section should be implemented.

The "objective" test emphasizes the automatic aspects of section 16(b) and operates by applying its provisions to every profit-making acquisition or disposition of securities which could possibly fit within the broad definitions of sections $3(13)$ and $3(14)$. Under this view, an insider who finds himself owning shares of stock after a transaction which he did not own before is considered to have "acquired" those shares within the language of section $3(13)$, and therefore to have "purchased" them within the meaning of section $16(\mathrm{~b})$. There is little or no inquiry into the manner in which the transaction was accomplished or the reasons for which it was entered into.

The "subjective" test, on the other hand, emphasizes the section's purpose "of preventing the unfair use of inside information," 15 and rests on the argument that it should not be applied unless this policy would be furthered. Before finding an insider's acquisition or disposition of securities to be a "purchase" or "sale" within the intent of the Act, it requires a showing that the possibility of the exploitation of inside information was present, on the grounds that absent such possibility of abuse, the deterrent force of the section is unnecessary. The inquiry under the subjective test is into the factual circumstances of the transaction. The primary effort here is to determine whether

13 While only 2 articles deal exclusively with the application of $\S 16(b)$ to mergers and merger-like transactions, Lang \& Katz, Liability For "Short-Swering" Trading in Corporation Reorganizations, 20 Sw. L.J. 472 (1966); 52 ColuM. L. Rev. 535 (1952), several others dealing more generally with the question of "purchase" and "sale" have included discussions of the merger situation. Cook \& Feldman, Insider Trading Under the Securities Exchange Act, 66 HARv. L. REv. 612, 626-28 (1953); R. Jennings \& H. Marse, Securities Regulation Cases and Materials 1063-64 (2d ed. 1968) ; Loss, supra note 8, at 1066-72; Meeker \& Cooney, The Problem of Definition in Determining Insider Liabilities Under Section 16(b), 45 VA. L. REv. 949, 975-79 (1959); Note, Short-Swing "Purchase and Sales" Under the Securities Exchange Act, 61 Nw. U. L. REv. 448, 460-64 (1966); Note, "Purchase" and "Sale" Under Section 16(b) of the Securities Exchange Act, 10 Syracuse I. REv. 296, 298-99 (1959); Note, 39 TEMr. L.Q. 467, 471 (1966).

14 Lowenfels; Section 16(b): A Neze Trend in Regulating Insider Trading, 54 CoRNell L. REv. 45, 45-46 (1968); Note, Short-Swing "Purchases and Sales" Under the Securities Exchange Act, 61 Nw. U. L. REv. 448, 455 (1966).

15 Securities Exchange Act of 1934, $\$ 16(\mathrm{~b}), 15$ U.S.C. $\$ 78 \mathrm{p}(\mathrm{b})$ (1964). 
there was any possibility that an insider in this general setting could have used information he had gained from his position to make a "short-swing" profit. This is as far as the investigation goes; it is concerned neither with the insider's intent in entering into the transaction nor with whether he actually did misuse inside information. ${ }^{10}$ Once it is discovered that a potential for abuse was present, it is irrelevant that there was no actual abuse.

The operation of these differing approaches can be illustrated by the two cases which occupy seminal positions in their development. Both involved the conversion of convertible securities, a type of transaction which has troubled the courts for some time and spawned much of the case law in the purchase and sale area. ${ }^{17}$ In Park \& Tilford $v$. Schulte, ${ }^{18}$ defendant insiders owned a majority of the plaintiff corporation's voting stock and a large amount of its convertible preferred stock. About the time a "spectacular" rise in the price of the corporation's stock was beginning, the convertible preferred was called for redemption, and the defendants soon after converted their preferred shares into common. The issue was whether the conversion was a "purchase" of the common stock, to be matched under section 16(b) with its subsequent sale less than six months later at a large profit. The court, with little difficulty, with an absence of policy analysis, and in a manner characteristic of the objective test, answered affirmatively, stating:

Whatever doubt might otherwise exist as to whether a conversion is a "purchase" is dispelled by definition of "purchase" to include "any contract to buy, purchase, or otherwise acquire." . . . Defendants did not own the common stock in question before they exercised their option to convert; they did afterward. Therefore they acquired the stock, within the meaning of the Act. ${ }^{19}$

The opposite result was reached several years later in Ferraiolo $v$. Nerman, ${ }^{20}$ in which the subjective test was first applied to a section

16 Since the test is not concerned with the insider's intent, the use of the word "subjective" is slightly misleading. In Heli-Coil Corp. v. Webster, 352 F.2d 156 (3d Cir. 1965), the court called the test "subjective" because "[w] hether or not a transaction 'can possibly lend itself to the speculation encompassed by Section 16(b)' must be determined to some degree at least by the minds of the finders of fact." Id. at 164. While this does not adequately justify the use of "subjective," the term has been used in this Comment for convenience in distinguishing the "subjective" from the "objective" test.

17 See cases cited notes 9-11 supra. For a complete analysis of the conversion situation, see Hamilton, Convertible Securities and Section 16(b): The End of an Era, 44 Tex. L. REv. 1447 (1966); Comment, Convertible Securities and Section 16(b): The Persistent Problems of Purchase, Sale and Debts Previously Contracted, 64 MiCH. L. REV. 474 (1966).

18160 F.2d 984 (2d Cir.), cert. denied, 332 U.S. 761 (1947).

$10 \mathrm{Id}$. at 987.

20259 F.2d 342 (6th Cir. 1958), cert. denied, 359 U.S. 927 (1959). 
16(b) convertible security case. After considering the legislative purpose and several prior cases, the court's much quoted statement of the subjective test was set forth as the standard for decision.

Every transaction which can reasonably be defined as a purchase will be so defined, if the transaction is of a kind which can possibly lend itself to the speculation encompassed by Section 16(b). ${ }^{21}$

The court proceeded to examine the transaction and concluded that the conversion "created no opportunity for profit which had not existed" 22 at the time the convertible security had been originally purchased some three years earlier. Since " $[\mathrm{t}]$ he transaction was not one that could have lent itself to the practices which Section 16(b) was enacted to prevent," ${ }_{23}$ it was held that there had been no "purchase" of the common stock obtained upon the conversion of the convertible preferred stock.

In concluding that the conversion created no opportunity for shortswing profit-making, the court relied on two major factors. First, the convertibility of the stock was protected against dilution by a contractual provision that the conversion ratio would be adjusted if there was any change in the number of outstanding common shares, and both the preferred and common stock were equally marketable. Once the market price of the common stock rose above the redemption price of the preferred, each stock would be proportionately valuable, with their relative market prices reflecting the conversion ratio. Since it would make no difference to a trader which stock was held, they were "economic equivalents." 24

The second factor in the decision was the supposed "involuntary" nature of the defendant's conversion. The defendant, an inactive director, converted after the preferred had been called for redemption at a price substantially below the then current market prices of the preferred and common stock. The court thought that it was unlikely that an insider would be able to take advantage of inside information where he could not control the timing of the conversion. This situation was contrasted with that in Park \& Tilford $v$. Schulte ${ }^{25}$ where the defendants owned a controlling interest in the issuing corporation and therefore could determine when, if ever, the preferred would be called for redemption.

Although the objective test was introduced early, it has been applied in full force in only a few cases, ${ }^{26}$ including at least one that is

21 Id. at 345. See Comment, The Scope of "Purchase and Sale" Under Section 16(b) of the Exchange Act, 59 YALE L.J. 510, 513 (1950).

22259 F.2d at 346.

$23 I d$.

$24 I d$. at 345 .

25160 F.2d 984 (2d Cir.), cert. denied, 332 U.S. 761 (1947).

26 Park \& Tilford, Inc. v. Schulte, 160 F.2d 984 (2d Cir.), cert. denied, 332 U.S. 761 (1947) ; Blau v. Hodgkinson, 100 F. Supp. 361 (S.D.N.X. 1951). 
relatively recent, ${ }^{27}$ and it has never exerted a dominant effect on the resolution of the "purchase and sale" cases. The subjective test, on the other hand, appears to have come into its own with Ferraiolo $v$. Nerman; since that decision, a trend in the cases toward the subjective approach has become clearly discernible. ${ }^{28}$

\section{Comparison and Evaluation of the "Subjective" and "ObJective" ApProaches}

The objective approach is based mainly on the concept of section 16 (b) as an automatic rule. It is asserted that the broad language of the section demonstrates that Congress judged that the only way to "prevent the unfair use of inside information" was to establish a test which applied without question to any transaction which came within its terms, thereby eliminating any possibility of error or laxity inherent in discretionary administration by the courts. ${ }^{29}$ Support for this position is drawn from the section's applicability, "irrespective of any intention" on the part of the beneficial owner, to "any profit . . . from any purchase and sale ... of any equity security . . . within any period of less than six months." 30 Further reliance is placed upon the definition of "purchase" and "sale" in terms broad enough to cover any transaction by which an insider acquires or disposes of stock. This language is thought to be clearly and unambiguously all-inclusive,

27 Heli-Coil Corp. v. Webster, 352 F.2d 156 (3d Cir. 1965), where it was stated: "On the other hand the test employed in Park \& Tilford employs the language of $\$ \S 3$ (a) (13) and $3(a)(14)$ in the manner in which we think Congress intended it to be used and that is in no sense a subjective one." Id. at 164 .

28 E.g., Petteys v. Butler, 367 F.2d 528 (8th Cir. 1966), cert. denied, 385 U.S. 1006 (1967) (no "purchase" of common shares acquired upon conversion of preferred); Blau v. Lamb, 363 F.2d 507 (2d Cir. 1966), cert. devied, 385 U.S. 1002 (1967) (no "sale" of preferred stock upon its conversion); Blau v. Max Factor \& Co., 342 F.2d 304 (9th Cir.), cert. denied, 382 U.S. 892 (1965) (conversion of one class of common stock into another not a "purchase" of the latter) ; Newmark v. RKO General, Inc., 294 F. Supp. 358 (S.D.N.Y. 1968) ("sale" of shares disposed of pursuant to a statutory merger) ; Lynam v. Livingston, 276 F. Supp. 104 (D. Del. 1967) (no "purchase" of common shares acquired upon conversion of debentures); Lowenfels, Section 16(b): A New Trend in Regulating Insider Trading, 54 CoRnel L. REv. 45 (1968). It should be noted the Second Circuit itself appears to have retreated from its position in Park \& Tilford, Inc. v. Schulte. In Blau v. Lamb, supra at 518, it stated:

Aside from the intimations to the contrary in Park \& Tilford, our court appears always to have recognized that in deciding whether a certain transaction is a Section 16(b) "purchase" or "sale" it is relevant to first consider whether the transaction in any way makes possible the unfair insider trading that Section 16(b) was designed to prevent.

29 Heli-Coil v. Webster, 352 F.2d 156, 165 (3d Cir. 1965); see also Blau v. Lamb, 363 F.2d 507, 519 (2d Cir. 1966), cert. denied, 385 U.S. 1002 (1967); Comment, Convertible Securities and Section 16(b); The Persistent Problems of Purchase, Sale, and Debts Previonsly Contracted, 64 Micr. L. Rev. 474, 478-79 (1966) ; Comment, Conversion to Avert Redemption Is Not a "Short-Swing" Purchase, 11 STAN. L. REv. 358, 359 (1959).

30 Securities Exchange Act of 1934, $\$ 16(\mathrm{~b}), 15$ U.S.C. $\$ 78 \mathrm{p}(\mathrm{b})$ (1964) (emphasis added). 
thereby preluding any interpretation by the courts. ${ }^{31}$ Finally, the mitigating power granted to the SEC to exempt transactions not "comprehended within the purposes of this subsection" 32 is used to draw the inference that courts should not create exceptions to section 16 (b) through the technique of narrow construction. ${ }^{33}$

An additional policy argument is that interpreting the section to cover without question any acquisition and disposition of securities within six months creates more certainty in its operation, thereby increasing its deterrent effect. The subjective test, it is claimed, lessens the deterrent effect of the section by allowing the insider to engage in speculation with the hope that he can defeat, or at least delay, recovery by entangling any litigation with an involved factual analysis of whether a potential for abuse was present. Furthermore, the subjective approach, by casting uncertainty upon the corporation's right to recover, may lessen its incentive to institute section 16(b) claims in the first place. Finally, it is argued that the subjective approach may lead to a lack of uniformity in the law by producing conflicts in interpretation among the circuits.

There are, however, many problems with the formulation and defense of the objective test. In the first place, it is not compelled by the statutory language. While the broad definitions of "purchase" and "sale" support the conclusion that any "unorthodox" transaction could be covered by section $16(b)$, it does not follow that such transactions must be so included. ${ }^{34}$ A contrary conclusion is suggested by the general, illustrative character of the definitions, introduced as they are by the word "include" and themselves incorporating the words they are attempting to define. Furthermore, the general definitional section of the Act is prefaced by the qualifying words-"unless the context otherwise requires." 35 From these words it appears that Congress did not intend the definitions to be interpreted literally, but that they were phrased this broadly in order to avoid putting any limit on the type of transaction which could come within the prohibitions of the Act.

31 Park \& Tilford, Inc. v. Schulte, 160 F.2d 984, 987 (2d Cir.), cert. denied, 332 U.S. 761 (1947); see Blau v. Lamb, 363 F.2d 507, 517 (2d Cir. 1966), cert. denied, 385 U.S. 1002 (1967).

32 Securities Exchange Act of 1934, §16(b), 15 U.S.C. $\S 78 \mathrm{p}$ (b) (1964).

33 See Meeker \& Cooney, The Problem of Definition in Determining Insider Liabilities Under Section 16(b), 45 VA. L. REv. 949 (1959); Brief for the SEC as Amicus Curiae, Pettys v. Northwest Airlines, 367 F.2d 528 (8th Cir. 1966), cert. denied, 385 U.S. 1006 (1967), cited in Hamilton, Convertible Securities and Section 16(b): The End of an Era, 44 Tex. L. Rev. 1447, 1476 n.107 (1966).

34 See Hamilton, supra note 33 , at 1453.

35 Securities Exchange Act of 1934, §3(a), 15 U.S.C. $\$ 78 c$ (a) (13), (14) (1964). A similar introduction is included in the general definitional section of the Securities Act of 1933, § 2, 15 U.S.C. § 77b (1964), and a comparably broad definition of the word "sale" may be found in the Securities Act of 1933, \$2(3), 15 U.S.C. \$77b (3) (1964). In its so-called "no-sale" rule, SEC Rule 133, 17 C.F.R. $\$ 230.133$ (1968), the SEC has concluded that the issuance and transfer of stock by the acquiring corporation in merger or stock-for-stock acquisition does not constitute a "sale" under the registration provisions of that Act, thus lending weight to the argument that the broad definitions in the Exchange Act also need not be interpreted literally. 
A better method of determining the scope of the definitions of "purchase" and "sale" in the context of "unorthodox" transactions would appear to tie in an examination of the policy underlying section 16(b) and a determination of the construction which best accomplishes its purposes in light of the facts of each case ${ }^{36}$ - the technique of the subjective approach. ${ }^{37}$

An understanding of the purposes of section 16(b) and a feeling for the type of transaction it was designed to prevent may be gained from an examination of the investigations preceding the enactment of the Securities Exchange Act. $^{38}$ These investigations revealed numerous instances in which corporate officials had abused their fiduciary positions by relying upon confidential corporate information to gain profits in their personal market activities through short-swing, in-andout trading. "In-and-out trading" refers to transactions where insiders, with advance knowledge of information, which when made public would cause a rise in the stock of the corporation, would purchase shares at current prices and then sell after the announcement of the news caused a rise in the market price. Conversely, with advance knowledge of information that would depress the price of the stock, insiders could sell stock at current prices and then buy it back when the price fell as a result of the announcement. Furthermore, insiders would occasionally create price fluctuations on their own by causing the corporation to pursue policies designed to create sudden fluctuations in the market price of its stock. ${ }^{39}$ Practices such as these were not only prevalent, but

36 Cf. SEC v. National Securities Inc., 89 S. Ct. 564 (1969). In holding certain alleged deceptive practices which accompanied a merger to be "in connection with the purchase or sale of any security" within the meaning of Securities Exchange Act of $1934, \S 10$ (b), 15 U.S.C. $\$ 78 j(b)$ (1964) and rule 10b-5 thereunder, SEC Rule 10b-5, 17 C.F.R. $\$ 240.10 b-5$ (1968), the Court stated that:

The relevant definitional sections of the 1934 Act are for the most part unhelpful; they only declare generally that the terms "purchase" and "sale" shall include contracts to purchase or sell. . . . Consequently, we must ask whether respondents' alleged conduct is the type of fraudulent behavior which was meant to be forbidden by the statute and the rule.

Id. at 572 .

37 See, e.g., Petteys v. Butler, 367 F.2d 528, 533, 536 (8th Cir. 1966), cert. denied, 385 U.S. 1006 (1967).

38 See Hearings on H.R. 7852 and H.R. 8720 Before the House Comm. on Interstate and Foreign Commerce, 73d Cong., 2d Sess. 85 (1934); Hearings ont S.84, S.56 and S.97 Before the Senate Comm. on Banking and Currency, 72d Cong., 1st Sess. \& 73d Cong., 1st \& 2d Sess. 6463-581 (1934); S. Rep. No. 792, 73d Cong., 2d Sess. 7-9 (1934); S. Rer. No. 1455, 73d Cong., 2d Sess. 55-68 (1934); H.R. REP. No. 1383, 73d Cong., 2d Sess. 13-14 (1934).

39 The section is primarily devised to prevent these sure-thing, in-and-out, speculations made with the benefit of advance information. The report of the Senate committee whose version was ultimately adopted states:

Such a provision will render difficult or impossible the kind of transactions which were frequently described to the committee, where directors and large stockholders participated in pools trading in the stock of their own companies, with the benefit of advance information regarding an increase or resumption of dividends in some cases, and the passing of dividends in others.

S. Rep. No. 792, 73d Cong., 2d Sess. 9 (1934) (emphasis added); see Smolowe v. Delendo Corp., 136 F.2d 231, 235 (2d Cir.), cert. denied, 320 U.S. 751 (1943). It is 
were looked upon as management's prerogative. Indeed,

[p]rior to the enactment of the Securities Exchange Act, profits from "sure thing" speculation in the stocks of their corporations were more or less generally accepted by the financial community as part of the emolument for serving as a corporate officer or director notwithstanding the flagrantly inequitable character of such trading. ${ }^{40}$

It was believed that the only way to eliminate these abuses was to enact a prophylactic rule. ${ }^{41}$ The common law, which required proof of actual use of inside information and which applied only to face-toface transactions (not anonymous transactions on a stock exchange) had proved ineffective. ${ }^{42}$ The draftsmen decided that the only remedy "effective for this reform was the imposition of a liability based upon

broad enough, however, to cover transactions where advance information was not the spur for in-and-out profit-making. It has been held, for example, that the section is applicable to a situation where the defendant, within a six-month period, purchases stock, becomes a director of the issuing corporation, and then sells the stock. Adler v. Klawans, 267 F.2d 840 (2d Cir. 1959); Marquette Cement Mfg. Co. v. Andreas, 239 F. Supp. 962 (S.D.N.Y. 1965); Blau v. A1len, 163 F. Supp. 702 (S.D.N.Y. 1958) ; cf. Stella v. Graham-Paige Motors Corp., 232 F.2d 299 (2d Cir.), cert. denied, 352 U.S. 831 (1956) (defendant's initial purchase made him a 10\% "beneficial owner"). Since the defendant was not an insider at the time of the original purchase, the statutory presumption that he had access to inside information at that time cannot be operative. Therefore, these cases cannot be based upon a rationale of preventing the typical in-and-out abusive transaction. It is arguable, however, that some such abuses may be prevented by these holdings. For example, the rule of this line of cases might act as a deterrent in a situation where a person, knowing he is about to become a director, buys stock with the intent to use the influence of his new position to cause a rise in the dividend rate, and to then quickly sell the stock after the anticipated market rise. This may in fact have been the motivation in Adler v. Klawans, supra, where the defendant director, immediately after he assumed office, used his influence to help cause the corporation to commence buying its own stock on the market.

On the whole, however, it appears undesirable to apply section $16(\mathrm{~b})$ to a situation where there is no possibility the insider could have had inside information when he made his original purchase (or sale). Cf. Stella v. Graham-Paige Motors Corp., supra (Hincks, J., dissenting). In such situations, although the later sale (purchase) may be made on the basis of inside information, the unfairness is independent of whether the two transactions were made in conjunction with each other as section 16 (b), which speaks in terms of "purchase and sale" and "sale and purchase," seems implicitly intended to require. It is actually a single-transaction abuse where section 16 (b) is brought into play only because of the mere happenstance that the original purchase (sale) took place less than six months earlier. It would be preferable to treat such situations under the general anti-fraud provisions of the Securities Exchange Act, $\S 10$ (b), 15 U.S.C. $\$ 78 \mathrm{j}(\mathrm{b})$ (1964) and Rule 10b-5 thereunder, 17 C.F.R. $\$ 240.10 \mathrm{~b}-5$ (1968).

4010 SEC Ans. Rep. 50 (1944).

41 Blau v. Lehman, 368 U.S. 403, 414 (1962).

42 See Cook \& Feldman, Insider Trading Under the Securities Exchange Act, 66 Harv. L. Rev. 385, 408-10 (1953) ; Comment, Short-Sreing "Purchases and Sales" Under the Securities Exchange Act, 61 Nw. U. L. Rev. 448, 449 n.9 (1966); Yourd, Trading in Securities by Directors, Officers and Stockholders: Section 16 of the Securities Exchange Act, 38 MICH. L. Rev. 133, 139-52 (1959), for a description of the common law liability of insiders who deal in the stock of their own corporations and a comparison of $\S 16$ (b) with the common law. 
an objective measure of proof." 43 The section was set up to operate as a "crude rule of thumb" 44 - to take the profits from transactions over such a short period of time, irrespective of the good faith or intent of the insider.

The rationale of the objective test mistakenly assumes that this "crude rule of thumb" approach necessarily bars any inquiry at all into the facts of each particular case. ${ }^{45}$ As discussed above, the purpose of the "rule of thumb" was merely to eliminate the necessity of establishing an insider's intent. ${ }^{48}$ There is nothing inconsistent with this purpose in the subjective test. It is specifically designed to look into the facts of the particular transaction only insofar as necessary to discover whether the possibility exists that the situation could in any way lend itself to an abuse of inside information. ${ }^{47}$ It does not make the insider's good faith and intent a factor in determining liability.

A second major criticism of the objective approach is that it can reach "manifestly absurd and unfair" ${ }^{48}$ results which involve "purposeless harshness." 49 Admittedly the section operates harshly when it is applied to transactions where the insider, if permitted, could show that he did not take advantage of inside information or that he did not have available any information from which he could have profited. There is a purpose to this harshness, however; Congress felt it indispensable in deterring actual abuses of inside information which potentially could occur in similar circumstances. ${ }^{50}$ On the other hand, the objective test carries this strictness too far in applying the section (1943).

43 Smolowe v. Delendo, 136 F.2d 231, 235 (2d Cir.), cert. denied, 320 U.S. 751

44 This often-quoted phrase is from a statement made by $\mathrm{Mr}$. Thomas $\mathrm{B}$. Corcoran, the chief spokesman for the draftsmen and proponents of the Act during the hearings on the proposed bill in which he explained the purpose of the section.

That is to prevent directors from receiving the benefits of short-term specula-

tive swings on the securities of their own companies, because of inside information. The profit on such transaction under the bill would go to the corporation. You hold the director, irrespective of any intention or expectation to sell the security within 6 months after, because it will be absolutely impossible to prove the existence of such intention or expectation, and you have to have this crude rule of thumb, because you cannot undertake the burden of having to prove that the director intended, at the time he bought, to get out on a short swing.

Hearings on $S .84, S .56$ and $S .97$, supra note 37 , at 6556-57.

45 Comment, Convertible Securities and Section 16(b): The Persistent Problems of Purchase, Sale, and Debts Previonsly Contracted, 64 MICH. L. REv. 474, 490 (1966) ; see Painter, The Evolving Role of Section 16(b), 62 Micr. L. Rev. 649, 665 (1964).

40 See text accompanying notes $41-44$ supra.

47 See also Painter, supra note 45 , at 677-78.

48 Petteys v. Butler, 367 F.2d 528, 535 (8th Cir. 1966), cert. denied, 385 U.S. 1006 (1967).

49 Blau v. Max Factor \& Co., 342 F.2d 304, 307 (9th Cir.), cert. denied, 382 U.S. 892 (1965).

50 See note 44 supra \& accompanying text. 
to situations where an insider could not have taken advantage of his position even had he been so disposed. Where there is not even a potential for misuse of inside information in a given situation, there can be nothing to deter, and application of section $16(\mathrm{~b})$ is unnecessary. ${ }^{\mathbf{} 1}$

The subjective test, therefore, which requires an initial finding that inside information could have at least potentially been misused for the personal profit of the insider, appears to be the preferable mode of interpreting section $16(\mathrm{~b}) ;^{52}$ the harshness of the section is brought to bear only where the deterrent effect is necessary. Support for the subjective test may be drawn from the language of the section, especially from its expressed statutory purpose "of preventing the unfair use of information which may have been obtained by an insider by reason of his relationship to the issuer. . . ." 53 The provisions which follow this preamble are clearly intended to be operative only insofar as they promote this policy; to apply those provisions where this purpose is not being furthered is to go beyond the expressed design of the statute. Furthermore, there can be no argument that the subjective test avoids these stringent, "crude rule of thumb," provisions since under that test, once a potential for abuse is discovered, they are applied in full force. Finally, by giving power to the SEC to exempt by regulation any transactions "not comprehended within the purpose of this subsection" 54 Congress itself appears to have recognized that certain transactions do not in any way lend themselves to unfair use of inside information, ${ }^{55}$ and that in those situations a method is needed to avoid a purposelessly harsh effect. This language, which recognizes the need for a means of restraining the operation of the section and which does not explicitly limit power to do so to the SEC, ${ }^{56}$ lends support to the use of the subjective approach by the courts. Responsibility for the enforcement of section 16(b) has been entrusted not to the SEC but to the courts through the medium of private suits. If they are to avoid using a "mechanistic" approach they must not be required to wait for the creation of exemptive rules which the SEC is often slow to promulgate. ${ }^{57}$

While the subjective test is the preferred method of judicial analysis under section 16 (b), it is clear that a similar analysis should also be employed by the SEC whenever it exercises its exemptive power under that section. The aim of the subjective test and the statutory

51 See Blau v. Lamb, 363 F.2d 507, 519 (2d Cir. 1966), cert. denied, 385 U.S. 1002 (1967).

62 See Lowenfels, supra note 28 , at 57-60.

53 Securities Exchange Act of 1934, § 16(b), 15 U.S.C. § 78p (b) (1964).

$54 I d$.

55 See Blau v. Lamb, 363 F.2d 507, 516 (2d Cir. 1966), cert. denied, 385 U.S. 1002 (1967); Meeker \& Cooney, supra note 33, at 975.

56 See Petteys v. Butler, 367 F.2d 528, 536 (8th Cir. 1966), cert. denied, 385 U.S. 1006 (1967).

57 Blau v. Max Factor \& Co., 342 F.2d 304, 307 n.5 (9th Cir.), cert. denied, 382 U.S. 892 (1965). 
mandate to the SEC are the same-to relieve from the operation of the section those transactions "not comprehended within the purpose of the subsection." 58 The only way to discover such cases is to use the subjective test: that is, factual analysis of the transaction in order to determine whether it could in any way lend itself to an unfair use of inside information. The same approach should be used both by the courts in dealing with the individual cases that come before them, and by the SEC in creating exemptions. The following discussion of the acquisition-merger situation is therefore based on an investigation of the possible opportunities for the kind of abuse of inside information that section $16(\mathrm{~b})$ was enacted to prevent. ${ }^{59}$

\section{Applying Section 16(b) to Mergers and Other CoRPORATE ACQUISTTIONS}

Corporate acquisitions transpire in a myriad of ways, the selected method turning largely on a consideration of the various corporate, financial and tax consequences. ${ }^{60}$ Almost always negotiated in secrecy and accompanied by rising stock prices, such transactions appear to present substantial opportunities for abuse. ${ }^{61}$ The ability to take advantage of such situations, however, depends upon the timing and sequence of the insider's trading, so a more detailed examination is required.

\section{A. "Cash-Analogous" Acquisition Transactions}

In a great number of acquisition transactions an analogy may be drawn with ordinary cash purchases and sales, where there is little question as to the applicability of section 16(b). All that distinguishes these transactions from ordinary cash purchases is that the consideration consists of securities rather than cash. This alone should not take the transactions out of the reach of section $16(\mathrm{~b}) .^{62}$

Typical are transactions where one corporation acquires control of another through an exchange of its shares either for the assets or for the controlling shares of the second, disappearing corporation, and the disappearing corporation itself or its controlling shareholders are also insiders of the acquiring corporation. In this type of case, as in that of the ordinary purchase for cash, the insider has complete control over his end of the bargain: he is in control of the consideration, be it cash, the assets, or stock of the disappearing corporation, which is to be exchanged for the stock of the corporation of which he is an insider. The insider in the cash-analogous exchange cannot control, though he may be able to influence, the acquiring corporation's entry into the

58 Securities Exchange Act of 1934, $\$ 16(b), 15$ U.S.C. $\$ 78 p(b)$ (1964).

69 See notes 38 \& 39 supra \& accompanying text.

60 See, e.g., G. McCarthy, AcQUisitions and Mergers 16-30 (1963).

61 Indeed, one commentator has gone so far as to state: "A merger or consolidation, perhaps more than any other transaction, involves many opportunities for abuses of confidential information." Cook \& Feldman, supra note 42 , at 626.

62 See Loss, supra note 8, at 1072. 
transaction. But in this respect he is in at least as good a position as the purchaser for cash, who cannot control the seller's decision to sell. The crucial factor is that in both cases the insider has information about what he is acquiring which gives him an unfair advantage over his outsider competitors in the market place, in negotiating the transaction and deciding whether to complete it. Whether the insider is the disappearing corporation itself, or a controlling stockholder in it, there is a possibility of short-swing speculation through the use of inside information not disclosed to the public at the time of the initial transaction.

Cases involving this type of cash-analogous exchange fall into two classes. First, there are the cases where the insider is an individual who owns a controlling interest in the disappearing corporation. In Fistel v. Christman ${ }^{63}$ the defendant, a director of the acquiring corporation, had previously owned ninety per cent of the shares of the disappearing corporation, and had several months earlier transferred a seventy per cent interest to the acquiring corporation. The transaction in question involved the exchange of approximately ten per cent more of the stock in return for the acquiring corporation's shares, which he sold less than six months later. His receipt of the stock of the acquiring corporation was conceded to be a "purchase." 64

A variation of this situation was presented in Booth $v$. Varian Associates. ${ }^{65}$ The defendants became directors of the plaintiff corporation in early 1959, shortly after it had acquired eighty per cent of the stock of a corporation which they had previously controlled. An agreement was promptly entered into to transfer the defendants' remaining twenty per cent interest to the acquiring corporation in 1962 in return for that number of the acquiring corporation's stock calculated on the basis of the market price on the day before closing in 1962 which would equal in value an agreed-upon sum of money. No one disputed that there had been a "purchase" of the acquiring corporation's shares; the major controversy concerned whether it had occurred in 1959 or 1962 . This was resolved by the court in favor of the later date. ${ }^{68}$

A similar case was Marquette Cement Manufacturing Co. $v$. Andreas, ${ }^{67}$ where the defendant was a director of the plaintiff Marquette Company and had been the owner of a controlling interest in the North American Cement Corporation. He was held to have "purchased"

63135 F. Supp. 830 (S.D.N.Y. 1955).

64 The complaint was dismissed, however, on the ground that the plaintiff had not established the existence of a recoverable profit. Id. at 832 .

B5 334 F.2d 1 (1st Cir. 1964), cert. denied, 379 U.S. 961 (1965).

66 The court adapted the subjective test to the solution of this problem: "The question ... [is] one of balancing the respective advantages and disadvantages of each contended for 'purchase' date and determining which one, if held to be the date of purchase, would be more likely to lend itself to the abuses the statute was designed to protect against." Id. at 4.

67239 F. Supp. 962 (S.D.N.Y. 1965). 
Marquette shares which were received by North American in exchange for all of its assets and subsequently distributed to him in liquidation.

A fourth case illustrating this type of situation is Blau v. Lamb ${ }^{68}$ where insiders of Air-Way Industries received newly-created convertible preferred stock of their own corporation in return for common stock of Lamb Industries in which they had previously held a ninety-seven per cent controlling interest. The district court held that this constituted a "purchase" of the Air-Way stock, stating that it was irrelevant that shares of stock rather than cash were the consideration. ${ }^{69}$ This holding was not contested upon appeal where the main question was whether the subsequent conversion of that stock constituted a "sale." to

The second type of case involves the exchange by an insider corporation of its assets for the acquiring corporation's stock. Typical of this category is Stella $v$. Graham-Paige Motors Corp. ${ }^{71}$ where there was held to have been a "purchase" 72 when the defendant corporation conveyed its automotive assets to the Kaiser-Frazer Corporation in exchange for Kaiser-Frazer stock, some of which it sold less than six months later. The court found that Graham-Paige achieved insider status as a "beneficial owner" by receiving in the exchange more than ten per cent of Kaiser-Frazer's outstanding stock. ${ }^{73}$ Even if less than ten per cent of the acquiring corporation's stock is received, insider status may nevertheless exist if the conveying corporation has "deputized" one of its officials to act in its behalf as a director of the acquiring corporation. ${ }^{74}$

A different problem is presented by another type of cash-analogous transaction: the exchange of stock in a third corporation between a parent and its wholly-owned subsidiary, or between two affiliated corporations both wholly-owned by the same parent, where one of the two is an insider of the third corporation. Section $16(\mathrm{~b})$ should not be applied in this situation. Since any gain obtained by one corporation through trading on the basis of inside information will be offset by a loss to another member of the same corporate family, there can exist none of the unfairness to the public or other stockholders at which the section is aimed.

6s 242 F. Supp. 151 (S.D.N.Y. 1965), aff'd in part and rev'd in part, 363 F.2d 507 (2d Cir. 1966), cert. denied, 385 U.S. 1002 (1967). For a discussion of the conversion aspects of this case, see text accompanying note 24 supra.

$60 \mathrm{Id}$. at 155 .

70363 F.2d at $516-17$.

71132 F. Supp. 100 (S.D.N.Y. 1955), rev'd on other grounds, 232 F.2d 299 (2d Cir.), cert. denied, 352 U.S. 831 (1956).

$72 I d$. at 106.

73 On this point both the district court, 132 F. Supp. at 103, and the court of appeals, 232 F.2d at 300, adopted the reasoning of District Judge Kaufman denying defendant's motion for summary judgment, 104 F. Supp. 957 (S.D.N.Y. 1952). See also note 39 sipra.

74 Cf. Blau v. Lehman, 368 U.S. 403 (1962); Rattner v. Lehman, 193 F.2d 564 (2d Cir. 1952). 
Two decided cases have adopted this reasoning. In Blau $v$. Mission Corp. ${ }^{75}$ the Mission Corporation acquired more than ten per cent of the Tide Water Associated Oil Company as part of a plan to acquire control over it. The Mission Corporation immediately exchanged these shares for newly issued shares of the Mission Development Company, its wholly-owned subsidiary which had recently been organized for the sole purpose of holding the Tide Water stock. In holding that this exchange did not constitute a "sale" of the Tide Water stock by the defendant Mission Corporation, the court stated:

[t] he transaction was, we think, a mere transfer between corporate pockets. To hold otherwise could be to place entirely undue stress on the corporate fiction reaching harsh and wooden results quite unnecessary to achieve the purposes of the act. Until, going beyond the corporate forms, some new individuals entitled to share in the ultimate profits enter the picture there has been no real sale of stock. ${ }^{76}$

This holding was followed in Blau v. Lamb ${ }^{77}$ where the defendant, Edward Lamb, through his personal holding company, defendant Lamb Enterprises, received Air-Way Industries stock from Lamb Industries in exchange for Lamb Industries stock. In the light of the fact that Lamb Enterprises and Lamb Industries were respectively $100 \%$ and $97 \%$ controlled by Lamb and his family, the court held that there had been no "purchase" of the Air-Way stock in the exchange. ${ }^{78}$

The limits of this principle are illustrated by a second transaction treated in Blau v. Mission Corp. ${ }^{79}$ It involved a similar exchange of Tide Water stock for Mission Development stock, but at a time when Mission had distributed some of its Mission Development shares so that it had only a sixty per cent interest in Development, whose stock was by then being actively traded on the New York Stock Exchange. At that time the Mission Development stock, although tied to the underlying Tide Water stock, was being bought and sold at prices involving "a substantial differential" from that stock. In holding that there had been a sale of the Tide Water stock in this exchange, the court raised the possibility that "an insider would possess information which when publicly released would depress Tide Water prices while enhancing those of Development" ${ }^{80}$ and presumably would exchange as much Tide Water for Development as he could. This holding illus-

75212 F.2d 77 (2d Cir.), cert. denied, 347 U.S. 1016 (1954).

$76 I d$. at 80 .

77363 F.2d 507 (2d Cir. 1966), cert. denied, 385 U.S. 1002 (1967).

${ }^{78} \mathrm{Id}$. at 525-26. The district court had refused to extend the Mission holding involving a $100 \%$-owned subsidiary to the instant situation involving a $97 \%$-owned subsidiary, fearing a lack of "any precise and generally applicable criteria for guidance in future cases," and feeling that the $3 \%$ difference was not "insignificant." $242 \mathrm{~F}$. Supp. 151, 159 (S.D.N.Y. 1965).

79212 F.2d 77 (2d Cir.), cert. denied, 347 U. S. 1016 (1954).

$80 \mathrm{Id}$. at 81 . 
trates once again the "cash-analogy" principle; the transaction is viewed as if cash were being exchanged for the Tide Water stock.

\section{B. Mergers and Other Non-"Cash-Analogous" Acquisition Transactions}

The analytical considerations in the "cash-analogous" transactions are not nearly as troublesome as those where the insider, while perhaps influential, is not in a position to dominate corporate decision-making. Such a situation typically will be presented in a merger between two large public corporations. Consider, for example, a statutory merger from the point of view of a non-controlling officer or director of the disappearing corporation. Although he may be able to exert some influence on the decision to merge, the final choice will be made, not by him, but by the corporate management as a whole. Furthermore, the exchange ratio, which will determine the number of shares of the surviving corporation's stock that he will ultimately receive, will be determined by negotiation between the managements of the corporations. Similar circumstances are present in other merger-like transactions such as a consolidation or an assets-for-stock exchange where the disappearing corporation, after selling its assets, distributes the acquiring coporation's shares as a liquidating dividend.

The insider is not in the same position as the participant in the cash-analogous exchange. $\mathrm{He}$ is not directly or indirectly a party to the exchange, since he cannot control the consideration at either end of the bargain. However, he is still able to use his advance knowledge about the merger to make short-swing profits by trading in the shares of the disappearing or acquiring corporation. Such opportunities for abuse require a different analysis from that which is appropriate for cash-analogous transactions. ${ }^{81}$

\$1 Even though it deals with similar corporate transactions, no analogy should be drawn from rule 133 under the Securities Act of 1933, SEC Rule 133, 17 C.F.R. $\$ 230.133$ (1968), the "no-sale" rule. That rule is based upon the theory that in this type of transaction, where the vote of all the shareholders is binding upon a single shareholder, who must accept the stock exchanged or assert his appraisal rights, the disposition occurs solely by operation of law, and there is no voluntary disposition of stock within the intended meaning of "sale" in the 1933 Act. Its effect is to exempt securities issued in such transactions from the registration requirements of $\$ 5$ and the prospectus provisions of $\$ 10$ of that Act. The rule has been criticized as not fulfilling the purposes of the 1933 Act. See Comment, Recent Developments in the No-Sale Theory Under the Securities Act of 1933: Proposed Revision of Rule 133, 47 CAL. L. REv. 112 (1959); Note, The SEC's No-Sale Rule and Exchanges of Securities Pursuant to Voluntary Reorganization, 67 HARv. L. REv. 1237 (1954). Furthermore, it has been restricted in application solely to that Act. Securities Exchange Act Release No. 3420 (1951); Holding Company Act Release No. 6340 (1945); E. I. DuPont de Nemours \& Co., 34 S.E.C. 531 (1953). The "no-sale" theory is based upon a "linguistic" interpretation. The SEC's No-Sale Rule, supra, at 1240. The argument that the word "sale" cannot include dispositions of securities in such reorganization transactions, should not be carried over to a situation where the potential for abuse is clear and the purposes of section $16(\mathrm{~b})$ can only be promoted by fitting the disposition of securities in such exchanges under the amply broad definition of "sale" in section 3(14). Indeed, the SEC itself argued as an amicus in Blau v. Hodgkinson, 100 F. Supp. 361 (S.D.N.Y. 1951), that the "no-sale" theory should not be applied to section 16(b) actions. See Loss, supra note 8, at 526-27. 
The analysis which follows rests on three assumptions about the market behavior of the stock of corporations involved in mergers. These assumptions are generally valid, although they do not hold true invariably. First, after the merger has been approved by the shareholders and announced publicly, the securities of each of the combining companies will tend to trade in substantially the same relation to each other as the ratio specified in the merger agreement. If they did not, arbitrage transactions would become profitable. ${ }^{82}$ Second, the market price of the disappearing corporation's stock will usually rise prior to the merger, since the exchange ratio will usually be favorable to it as an inducement to enter into the transaction. ${ }^{83}$ Finally, the stock of the surviving corporation will usually rise in value even after the merger is consummated. ${ }^{84}$ Although the many factors which influence stock prices cause this phenomenon to be far from universal, its consistent appearance is probably due to an assumption on the part of investors that the corporation's management would not have agreed to the merger if they had not thought it would benefit the corporation, or to a belief that bigness is in itself advantageous.

Since the timing and sequence of stock purchases, sales and exchanges pursuant to a merger is central in this analysis, three basic periods must be considered in determining the potential for abuse of inside information. The period prior to the stockholder approval and public announcement of the merger will be referred to as the "preapproval" period, the interval between the approval and announcement and the subsequent consummation of the merger ${ }^{85}$ as the "interim" period, and the period after the merger has been consummated the "post-acquisition" period. Given these three periods, there are four combinations of time of purchase, time of sale and total holding period to be considered in the prototype situation where the insider purchases shares of the "acquired" or "disappearing" corporation (corporation $A$ ), exchanges his $A$ shares for those of the "acquiring" or "surviving"

82 Loss, supra note 8, at 1059; Cook \& Feldman, Insider Trading Under the Securities Exchange Act, 66 HARv. L. REv. 612, 626 (1953). Potential obstacles to merger, such as anti-trust complications or the need for favorable tax rulings, may produce some discount between the merger partners' stock. However the difference is likely to be minimized by speculative arbitrage.

83 See G. McCartHy, sipra note 60 , at 94-102. A study of 58 business combinations consummated between 1955 and 1961 revealed that in 47 of those transactions the acquiring company paid a premium in the market value of its stock exchanged for that of the acquired company.

84 B. Crane, The Sophisticated Investor 55 (rev. ed. 1964); L. Welson, The Effect of Mergers on Earnings Per Share and Market Price, 1960 (unpublished MBA thesis in the Lippincott Library of the Wharton School, Univ. of Penna.).

85 This is not necessarily the date upon which the physical exchange of stock certificates occurs, but rather the date upon which the insider's rights and obligations to exchange his share according to the terms of the acquisition agreement have become irrevocably fixed. This date is ordinarily determined by state law and may depend upon such things as the filing of the certificate of merger, the approval of interested agencies, or the fulfilling of various contractual closing conditions. See Cook \& Feldman, supra note 82, at 627 n.18; Lang \& Katz, Liability for "Short-Swing" Trading in Corporate Reorganizations, 20 Sw. L.J. 472, 499-502 (1966). 
corporation (corporation $B$ ) pursuant to the merger, and then sells his $B$ shares: ${ }^{86}$

1. Purchase of $A$ shares during the interim period and sale of the $B$ stock obtained in the merger exchange less than six months later during the post-acquisition period.

2. Purchase of $A$ shares during the interim period and sale of the $B$ stock obtained in the merger exchange more than six months later during the post-acquisition period.

3. Purchase of $A$ shares during the pre-approval period and sale of the $B$ stock obtained in the merger exchange more than six months later during the post-acquisition period.

4. Purchase of $A$ shares during the pre-approval period and sale of the $B$ stock obtained in the merger exchange less than six months later during the post-acquisition period.

These situations will first be considered from the point of view of an insider of $A$ who becomes a $B$ insider upon the merger.

\section{Purchase of $A$ Stock, Interim Period; Sale of $B$ Stock, Post-Acquisition Period; Holding Period Less Than Six Months}

Since during the interim period the market values of the shares of $A$ and $B$ will tend to maintain substantially the same relation as the agreed upon exchange ratio, they will be economically equivalent. ${ }^{87}$ It makes no difference to one who has inside information whether he purchases $B$ shares and quickly sells $B$ or purchases $A$ stock, exchanges, and then sells $B$. The former transaction, if accomplished within a six-month period by a $B$ insider, is clearly within the reach of section 16(b). The latter presents equal opportunities for the abuse of inside information.

By hypothesis, the fact of the merger has already been publicly announced. However, $A$ stock may be bought in this period in order to take advantage of any other as yet undisclosed information-the public disclosure of which will cause a rise in the price of $B$ stock. Even though the defendant does not become a $B$ insider until after the merger, he is likely to have inside information about $B$ before it, since

86 Since $\$ 16(\mathrm{~b})$ applies to "sales and purchases" as well as "purchases and sales," a similar situation would exist where an insider sells $B$ stock then exchanges his prior holdings of $A$ shares for $B$ in connection with the merger. However, since the opportunities for abuse appear to be fewer, the major focus of analysis will be the "purchase and sale" situation. Inasmuch as the profitability of a "sale and purchase" trade depends upon an expected fall in price, it will be very rarely presented in a merger situation which usually involves rising prices. See notes 83-84 \& accompanying text.

87 But see note 82 supra. 
merging corporations will generally confer closely in the course of premerger negotiations. For example, if the two corporations are of equal bargaining strength, corporation $A$ probably will have examined $B$ 's entire financial and competitive position with great care, with the result that it knows far more than the public possibly could about the company and any special factors which may cause a rise in the price of its stock.

However, section 16(b) speaks only of the "equity securities of such issuer," ${ }^{88}$ language which seems to indicate plainly that the shares of a single corporation are involved so that a purchase of $A$ stock cannot be matched with a sale of $B$ stock. ${ }^{89}$ Therefore to bring this transaction within the coverage of section 16(b), the merger exchange must be treated as a "sale" of $A$ stock and a "purchase" of $B$ stock to be matched with the actual purchase of $A$ shares and the actual sale of $B$ shares.

Support for this treatment may be drawn from the SEC's rule dealing with convertible securities. In rule $16 \mathrm{~b}-9^{90}$ the SEC recognized that only in certain circumstances does the economic equivalence of the convertible security and the underlying common stock (caused by their parallel trading) lend conversion of those securities to potential abuse of inside information. It provides that no section 16(b) "sale" or "purchase" occurs when one security is converted into another pursuant to the terms of the corporate charter or other governing instrument, except where there has been a purchase of the convertible and a sale of the underlying common, or a sale of a convertible and an ordinary purchase of the common, within a period of six months (which includes the conversion). The instant situation is also characterized by the market-equivalency of the shares of the two companies caused by their parallel trading during the interim period. Since the total period involved is less than six months, there should be considered to have been a "sale" of $A$ stock and a "purchase" of $B$ stock in this exchange. ${ }^{91}$

88 Securities Exchange Act of 1934, §16(b), 15 U.S.C. $\$ 78 p(b)$ (1964).

89 For this reason it also appears that $\S 16(b)$ cannot directly cover the situation where the insider' sells $A$ during either the interim or the pre-approval period and then buys $B$ less than 6 months later during the post-acquisition period.

9017 C.F.R. $\$ 240.16 \mathrm{~b}-9$ (1968).

91 Cf. Cook \& Feldman, supra note 82, at 626; Loss, supra note 8, at 1059.

It should be noted that this discussion assumes that the $A$ insider becomes a $B$ insider as a result of the merger. However, there may be case where the $A$ insider neither becomes an officer or director in $B$, nor acquires the requisite $10 \%$ of $B$ stock. The policy of section 16(b), removing the profits from transactions based on the use of insider information, would require liability of the insider on the profits of the entire set of transactions, from the purchase of $A$ through to the sale of $B$, since all such profits may be attributable to the use of insider information. Nevertheless, if the $A$ insider does not become a $B$ insider, the plain language of the statute would seem to preclude section $16(\mathrm{~b})$ coverage of the profits derived from the "purchase" of $B$ stock in the merger exchange and its subsequent sale, limiting the insider's liability to the profit from the purchase of $A$ and its "sale" in the exchange. 
2. Purchase of $A$ Stock, Interim Period; Sale of $B$ Stock, Post-Acquisition Period; Holding Period More Than Six Months

On the basis of the reasoning applied to the situation above, there is no potential for abuse of inside information where the various elements of the transactions occur in this sequence. Again, since the purchase of $A$ stock is made during the interim period, for trading purposes it is analogous to a purchase of $B$ stock. While an insider could have at his disposal a great amount of inside information, the fact that he has waited for more than six months between his "in" and "out" transactions should save him from liability, since that time period was determined by Congress as the point outside of which inside information could not be unfairly used. Rule $16 \mathrm{~b}-9$ may be used to support this result, the situation again involving an economic equivalency between the $A$ shares and the $B$ shares during the interim period. Under that rule no "purchase" or "sale" is involved if the total period involved is greater than six months. Accordingly, the exchange of shares in this situation should be considered neither a "sale" of $A$ stock nor a "purchase" of $B$ stock.

\section{Purchase of $A$ Stock, Pre-Approval Period; Sale of $B$ Stock,} Post-Acquisition Period; Holding Period

\section{More Than Six Months}

This situation presents some of the thorniest problems in the area. While the reasoning underlying the analogy with rule $16 \mathrm{~b}-9$ remains controlling, the result it leads to here is that the purchase of $A$ and its exchange should be treated as section 16(b) transactions, although the acquisition of $B$ and its sale should not.

The rationale of rule $16 \mathrm{~b}-9$ rests on the concept of economic equivalency. The effect of the conversion ratio is to ensure that the market value of the convertible at any given moment is the same as the market value of the common into which it could be converted. To the speculator, conversion alone cannot be regarded as a profit-yielding transaction.

At the time of the exchange in the hypothetical under consideration, the shares of the two corporations will have become approximately equivalent. What distinguishes this situation is that the shares are not equivalents at the time the insider purchases $A$ shares. Before the announcement of the merger and the exchange ratio, the market values of the two shares are independent. The exchange ratio is usually advantageous to $A^{\mathbf{2} 2}$ and its announcement will cause a rise in the value of $A$ stock to bring it into line with the $B$ stock into which it has become convertible. This presents considerable opportunity for short-swing 
speculation to the insider who buys before the announcement. ${ }^{93}$ His position is no different than if he were to buy $A$ stock before announcement of the merger and then sell for cash within six months rather than exchange into $B . .^{94}$

It may, however, be argued that the exchange is not enough of a realization to constitute a section 16 (b) "sale," and that it should be treated as such only when the purchase of $A$ and the sale of $B$ occur within six months. ${ }^{95}$ In other words, it may be contended that this situation is completely analogous to the conversion situation covered by rule $16 \mathrm{~b}-9$.

This argument is premised on the congressional judgment which is embodied in the statute that there is no need to deter short-swing speculation where the purchase which initiates the series of transactions is separated by more than six months from the sale which terminates it. There is no incentive to speculate where the insider is obliged to hold the original security (or the equivalent security the insider received in exchange for it) for longer than six months, since if he does not sell quickly, market fluctuations are likely to wipe out his profits.

But this argument does not hold well in the hypothetical under discussion. First, this series of transactions is not a unit for section 16(b) purposes. $A$ and $B$ securities are not equivalents until the announcement of the merger. It is this announcement which generates the short-swing profit by raising the price of $A$. Second, there is little danger that the value of $B$ will fall, since after a merger the price of the stock of the acquiring corporation generally rises or at least remains stable. $^{96}$ It is very unlikely that the possibility of its falling is sufficient to deter an insider from speculating on advance knowledge of the merger pending its announcement. Therefore, the exchange of $A$ should be treated as a "sale" so that liability attaches if it occurs within six months of the original purchase.

Two possible objections to such treatment remain to be considered. The first is that some allowance should be made for the fact that the completion of the merger is contingent on shareholder approval after full disclosure of the main features of the plan. ${ }^{97}$ There is no possibility that this procedure will put the other shareholders in

93 In commenting on the SEC's consideration of various proposals for exemptive rule-making, the General Counsel of the SEC has stated:

One of the problems in the merger area, and reorganization is frankly, that historically stock transactions in anticipation of an undisclosed merger have been one of the problem areas in the use of insider information.

Current Problens in Securities Regulation, 21 Bus. LAw. 117, 209 (1965) (remarks of Philip Loomis, Jr.).

84 Cook \& Feldman, supra note 82 , at 626-27.

${ }^{85}$ Cf. Lang \& Katz, supra note 85 , at $486-87$.

${ }^{96}$ See note 84 supra \& accompanying text.

97 See, e.g., ABA-ALI MODEL Bus. CoRp. $\$ 67$ (1960). 
the same position as the insider, since he has already made his purchase before the proposal is submitted to the shareholders. ${ }^{98}$ The risk of shareholder disapproval is small since approval is almost always obtained.9 And even if there is some risk involved, this does not alter the fact that profits, if any, have been made through abuse of insider information. These profits can hardly be legitimized because a greater degree of risk attended their creation.

The second objection is that the exchange of $A$ stock cannot be a "sale" here since it is "forced" on the non-controlling insider by the vote of management and other shareholders. The fact that an exchange was "involuntary" has been accorded primary significance in several of the cases under section 16(b), especially those involving conversions, but it has never been considered determinative. ${ }^{100}$ The crucial question is whether the transaction presents an opportunity for trading on inside information, and "voluntariness" is relevant only insofar as it bears on this question. Here an opportunity for the abuse of inside information clearly is present. The insider can hardly complain since the reason he bought the stock was his hope of making profits from this "forced" sale.

Different considerations are involved in the question whether the acquisition of $B$ stock should be considered a "purchase." Here the rule 16b-9 analogy should be controlling. Except for the profits derived from the advance knowledge of the rise in the price of $A$ stock, which have been purged by treating the exchange of $A$ as a "sale," the sequence of transactions from the purchase of $A$ to the sale of $B$ may be regarded as a unit for section 16 (b) purposes, since once the price of $A$ stock comes into the relation with the price of $B$ stock fixed by the merger ratio, the two are equivalents. The only purpose of treating the exchange as a "purchase" or "sale" is to get around the statutory language, which refers only to a single class of stock of a single issuer, in order to bring the transaction within the coverage of section 16(b). This reasoning is not applicable when, as in the hypothetical under discussion, the sequence of transactions does not take the defendant "in" and "out" again within six months. Since the

98 This situation may be compared with that in Roberts v. Eaton, 212 F.2d 82, 85 (2d Cir.), cert. dettied, 348 U.S. 827 (1954), where before approval, full disclosure had been made that the insider intended to sell immediately after approval the stock he expected to receive in the reclassification in return for shares which he had held for a considerable period of time. This disclosure and the "time-consuming" ratification by the stockholders were important factors in the court's decision that there had been no "purchase" of the newly-issued shares. Id. The other stockholders could be put on the same footing as the insider by this disclosure since the only information which could have been taken advantage of was the knowledge that the insider intended to sell out immediately. This information was given to the other stockholders at a time when they could still have acted on it if they desired.

99 J. Clendenin, Introduction to Investments 62 (4th ed. 1964).

100 E.g., Petteys v. Butler, 367 F.2d 528 (8th Cir. 1966), cert. denied, 385 U.S. 1006 (1967); Ferraiolo v. Newman, 259 F.2d 342 (6th Cir. 1958), cert. denied, 359 U.S. 927 (1959) ; Lynam v. Livingston, 276 F .Supp. 104 (D. Del. 1967) ; cf. Blau v. Lamb, 363 F.2d 507, 520 n.16 (2d Cir. 1966), cert. denied, 385 U.S. 1002 (1967). Cf. note 81 supra. 
congressionally prescribed period has been exceeded, the entire sequence cannot be regarded as allowing abuse of inside information, and therefore the acquisition of $B$ stock should not be regarded as a "purchase."

Although this produces the result that the same exchange is viewed as a "sale" of $A$ but not a "purchase" of $B$, the inconsistency is merely verbal. Whether an acquisition is a "purchase" or a disposition of a "sale" in the context of "unorthodox" transactions should be determined by the policy of the statute. Here the abuse contemplated by the statute may be corrected by treating the exchange of $A$ as a "sale," but not the exchange of $B$ as a "purchase." 101

One special situation remains to be considered in which such an interpretation may lead to harsh results. This is the situation where no merger was contemplated by the disappearing corporation at the time of the original purchase. Such a situation exists where corporation $X$ seeks to acquire control of corporation $Y$ and through a tender offer purchases enough $Y$ shares to make it a "beneficial owner" for the purposes of section 16(b), but not enough to enable it to control $Y$. Corporation $Y$, however, does not wish to be taken over by $X$ and to avoid this result enters into a merger with a third corporation $Z{ }^{102}$ This situation is not unlikely in the light of the recent growth of the use of the tender offer ${ }^{103}$ and the "defensive merger" as a technique to fight it. ${ }^{104}$ Since the plan to merge was conceived only after the original purchase by corporation $X$, it cannot possibly have had advance knowledge of the $Y-Z$ merger.

Since the only reason for treating the exchange of $A$ as a "sale" is to deter short-swing speculation in anticipation of merger, the

$101 \mathrm{~A}$ very sophisticated argument could be made that similar policy-oriented treatment should be accorded in the following situation: $B$ is much larger than $A$, $B$ merges into $A$ in an "upside-down" merger, and an $A$ insider with advance knowledge of the merger buys $A$ stock before the merger is announced and sells more than 6 months later. Normally there would be no $\$ 16(\mathrm{~b})$ recovery in this situation since the $A$ stock was held longer than 6 months. It could be argued, however, that there are two types of $A$ shares involved here- "old" $A$ and "new" $A$, with the latter having substantially the same market characteristics as $B$ stock.

Therefore, even though the insider has retained the same certificates, he should be considered as having sold his "old" $A$ stock and "purchased" his "new" $A$ stock upon the occurrence of the merger, so that the situation receives the same treatment as the one where the $B$ corporation is the survivor and $B$ shares are actually received in exchange for the $A$ shares. Such an argument would not appear to have much chance of success; without any actual exchange of shares it would be difficult to convince a court there had been any "acquisition" or "disposition" of shares of stock as required by the definitions of "purchase" and "sale". Cf. R. JENNINGS \& H. MARSH, Securities Regulation Cases and Materials 1064 (2d ed. 1968) ; Cook \& Feldman, Insider Trading Under the Securities Exchange Act, 66 HARv. L. REv. 612, 627 (1953).

102 These are the basic facts of the Westinghouse Air Brake Co. and American Standard, Inc., merger which was entered into by Wabco after an attempted take-over by the Crane Company. N.Y. Times, June 11, 1968, at 63, col. 4.

103 See genterally Cohen, Tender Offers and Take-over Bids, 23 Bus. LAw. 611 (1968); Fleischer \& Mundheim, Corporate Acquisition by Tender Offer, $115 \mathrm{U}$. PA. L. REv. 317 (1967).

104 See Tactics of Cash Takeover Bids, Harv. Bus. Rev., Mar.-Apr., 1967, at 135; Buying Into a Company Via the Tender Offer, Bus. WeEK, Feb. 26, 1966, at 38; The Takeover Titans, FINANCE, Aug. 1967, at 8; Rukeyser, Getting Tongh with Tenders, Fortune, Aug. 1967, at 108. 
rationale of the subjective test requires that a defendant be permitted to show that no merger was contemplated at the time of the initial purchase. $^{105}$

\section{Purchase of $A$ Stock, Pre-Approval Period; Sale of $B$ Stock, Post-Acquisition Period; Holding Period Less Than Six Months}

Given this sequence, exploitation may involve two different sorts of inside information. The insider may have advance knowledge of the merger and a proposed exchange ratio favorable to $A$-facts which will cause the price of $A$ stock to rise as soon as they are learned by the public. He may also have gained material inside information about corporation $B$ which when disclosed will inflate the price of $B$ stock. By purchasing $A$ stock prior to the public announcement of either of these sorts of information and selling the $B$ stock obtained in the merger less than six months after the original purchase, the insider may be in a position to make substantial profits. Since a potential for abuse is clearly present in this situation, the exchange of $A$ shares for $B$ shares in the merger should be considered a "sale" of $A$ stock and, unlike hypothetical $C$, also a "purchase" of $B$ stock to be matched respectively with the original cash purchase of $A$ stock and the final cash sale of $B$ stock.

Newmark v. RKO General, Inc., ${ }^{100}$ a very recent case, the first involving a statutory merger, fits within this hypothetical. The case arose out of the 1967 merger of Central Airlines into Frontier Airlines. The defendant, RKO, held fifty-six per cent of the stock of Frontier when the managements of the two companies reached a tentative agreement that their companies would merge. About a month later, one day before the two airlines executed a formal agreement of merger and announced it to the public, RKO entered into agreements with several Central stockholders to purchase forty-nine per cent of the outstanding Central common and a large amount of Central's convertible debentures. As part of these agreements Central stockholders owning approximately sixty-six per cent of the corporation's common stock promised to vote for the merger. The merger subsequently received the requisite shareholder and Civil Aeronautics Board approval, and RKO soon thereafter paid for and received the Central stock and debentures for which it had previously contracted. Less than six months after RKO's original agreement to purchase the Central securities, the merger was consummated and Frontier stock was received by RKO in return for its Central holdings.

The key holding of the court was that the disposition of the Central securities upon execution of the merger constituted a "sale"

105 For other proposals dealing with this hypothetical situation, see Munter, Section 16(b) of the Securities Exchange Act of 1934: An Alternative to "Burning Down the Barn in Order to Kill the Rats," 52 CORNELl L. Rev. 69, 91-92 (1966).

106294 F. Supp. 358 (S.D.N.Y. 1968). 
for the purposes of section $16(\mathrm{~b})$. The court concluded ${ }^{107}$ that it was compelled to use the subjective test since the objective test had been "discarded" in the Second Circuit by Blau v. Lamb. ${ }^{108}$ It noted that RKO could have been "gambling," when it entered the purchase contract, that the exchange ratio, of which it had prior knowledge, would be favorabie to it with respect to the relative prices of the Central and Frontier stock. The court further stressed that RKO's large interest in the two corporations enabled it to influence the speed, timing and possibly even the outcome of the merger. This situation presented a very substantial possibility of abuse, since RKO could have entered into these dealings expecting that the exchange ratio would be favorable to it, but knowing that if the ratio turned out to be unfavorable it could force abandonment of the merger. It was in a position to do this by using its control of Frontier to refuse to consent to conditions placed upon the merger by the $\mathrm{CAB}$, thereby breaking the purchase agreements with the several Central stockholders which had as a condition precedent the consummation of the merger. These extra factors created a possibility of abuse even greater than that which would exist on the bare facts of the hypothetical under consideration.

\section{Changed Factors When the Defendant Is Originally an Insider of Corporation $B$}

Having considered these four prototypes from the perspective of a defendant who is originally an insider of $A$, it is necessary to repeat the analysis from the point of view of a defendant who is originally an insider of $B$. It would appear that exactly the same potential for abuse is present, since the $B$ insider will have access to the exact same information which could be unfairly used by the defendant who started as an $A$ insider. This results from the necessarily two-sided conduct of merger negotiations. It may be assumed for the purposes of the section that any $B$ insider, whether an officer, director, or "beneficial owner," will have access to any information learned by the $B$ corporation management as to the progress of the negotiations or the probable exchange ratio. Furthermore, as an insider in corporation $B$, the defendant will certainly have access to inside information concerning his own company. Therefore, the same rules should apply to speculators who begin as insiders of $B$ as apply to those who begin as insiders of $A$. However, differences in the amounts of profits recovered will turn on whether the particular defendant ever becomes an insider of $A$ as well as $B$.

\section{Situations Where the Insider Is an Insider of One But Not Both Corporations}

The preceding analysis has assumed that the $A$ insider subsequently becomes a $B$ insider and vice versa. The language of section 
16(b) leaves no doubt that an insider is liable only for profits from trading in the shares of his own corporation. In the exchange situation, although the entire series of transactions is a unit, it can only be treated as such by calling the exchange a "purchase" and "sale" if the defendant is an insider of both corporations. ${ }^{109}$ For instance, the $B$ insider who is not an $A$ insider cannot be held liable for profits from the purchase and exchange of $A$ stock. Yet, it is in the nature of mergers that an inside position in one corporation gives the speculator inside information about the other. ${ }^{110}$ If investigation reveals the dimensions of the problem to be substantial, ${ }^{111}$ section $16(\mathrm{~b})$ should be amended to provide that when stock is held to have been "purchased" or "sold" pursuant to an exchange of shares in a merger, an insider of one of the combining corporations should be deemed an insider of the other.

\section{ConcLusion}

The application of section $16(\mathrm{~b})$ to mergers and other corporate acquisitions should be based upon the same approach adopted by a majority of the courts in dealing with other "unorthodox" exchanges. Before a transaction is subjected to the strict provisions of the section

109 See note 91 supra.

110 In practice, the problem is less frequently encountered when the defendant is originally an insider of $A$, since he is more likely to become an insider of $B$ than a $B$ insider is to become an $A$ insider. Corporation $B$ may regard important stockholders or officers in Corporation $A$ as valuable assets because of their knowledge of the working of $A$, and may invite them to be officers or directors of $B$. See, e.g., Booth v. Varian Associates, 334 F.2d 1, 2 (1st Cir. 1964), cert. denied, 379 U.S. 961 (1965); Marquette Cement Mfg. Co. v. Andreas, 239 F. Supp. 962, 965 (S.D.N.Y. 1965). Also a major stockholder of $A$ will frequently end up holding more than $10 \%$ of the stock of $B$. On the other hand, it is unlikely that a $B$ insider will become a director or officer of $A$; and if he is out to speculate by buying $A$, he will, if he has legal advice, be careful to buy less than $10 \%$ of $A$ stock.

111 Whatever gaps there may be in the coverage of section $16(\mathrm{~b})$ may be filled by the possibility of damage actions based on rule $10 \mathrm{~b}-5$ under the Securities Exchange Act. The rule states:

It shall be unlawful for any person, directly or indirectly, by the use of any means or instrumentality of interstate commerce, or of the mails or of any facility of any national securities exchange,

(a) To employ any device, scheme, or artifice to defraud,

(b) To make any untrue statement of a material fact or to omit to state a material fact necessary in order to make the statements made, in the light of the circumstances under which they were made, not misleading, or

(c) To engage in any act, practice, or course of business which operates or would operate as a fraud or deceit upon any person,

in connection with the purchase or sale of any security.

17 C.F.R. $\$ 240.10 \mathrm{~b}-5$ (1968). Under the rule it has been held:

[A]nyone in possession of material inside information must either disclose it to the investing public, or, if he is disabled from disclosing it in order to protect a corporate confidence, or he chooses not to do so, must abstain from trading in or recommending the securities concerned while such inside information remains undisclosed.

SEC v. Texas Gulf Sulphur Co., 401 F.2d 833, 848 (2d Cir. 1968), cert. denied, sub nom. Coates v. SEC, 37 U.S.L.W. 3399 (U.S. Apr. 22, 1969) (No. 897), and Kline v. SEC, 37 U.S.L.W. 3399 (U.S. Apr. 22, 1969) (No. 937). 
it must be shown to be of a kind which lends itself to the abuses which section 16 (b) was enacted to prevent. Since the exchange of shares in a merger or similar transaction lends itself to the possibility of unfair use of inside information only when certain combinations of timing and sequence are present, only in those circumstances should section 16 (b) be applicable.

Nevertheless, full responsibility should not be left to the courts. Since it has been shown that in many situations the purposes of section 16(b) will not be promoted by applying it to merger-acquisition transactions, the SEC should be encouraged to use its exemptive power to permanently eliminate all doubt as to its applicability in these situations. ${ }^{112}$ It is preferable that section $16(\mathrm{~b})$ cases should result in litigation as rarely as possible. The deterrent effect of the section operates much more efficiently when liability or lack of liability is clear. Even if all courts were to adopt a subjective approach this would still involve a large amount of interpretation on the part of each court. There is no guarantee therefore that all courts will reach the same, "correct" result in finding a particular type of transaction not subject to the abuses section 16(b) was designed to prevent. Furthermore, some types of transactions may be so completely deterred that they never reach the courts; the potential liability may be such that an insider will be sure to be careful and never exchange shares within a six-month period in that type of transaction. ${ }^{113}$

112 See Kramer, An Examination of Section 16(b), 21 Bus. Law. 183, 188-93 (1965) ; cf. Halloran \& Calderwood, Effect of Federal Regulation on Distribution of and Trading in Securities, 28 GEO. WASH. L. REv. 86 (1959) (suggesting congressional amendments to $\$ 16(\mathrm{~b})$ to encourage the SEC more readily to adopt exemptive rules).

The SEC has already dealt with certain aspects of acquisition transaction in rules 16b-6(c), 17 C.F.R. $\$ 240.16 b-6$ (c) (1968), and 16b-7, 17 C.F.R. $\$ 240.16 b-7$ (1968). Designed to limit recovery solely to the short-term portion of the profits incident to sales of stock purchased upon the exercise of an option, rule $16 \mathrm{~b}-6$ was amended in 1954 to exempt certain sales completely. Rule $16 \mathrm{~b}-6(\mathrm{c})$ provides that the disposition of shares pursuant to a merger, consolidation, reclassification or assets-for-stock exchange shall not be treated as a sale, where such stock was purchased through the exercise of an option acquired more than 6 months earlier or pursuant to the stock option terms of an employment contract entered into more than 6 months earlier.

Rule 16b-7 recognizes that the significance of certain types of mergers to the stockholders of the disappearing company is so minor that the potential for earning a trading profit through advance knowledge of the merger is negligible. Where a large corporation merges into a very small corporation in a "downstairs" merger, while the shareholders of the large corporation will receive stock in a different corporation, the attributes of that stock will be substantially the same as the stock which they have turned in. A similar situation will exist where a parent merges into its nearly wholly-owned subsidiary. Providing for these situations in rule 16b-7, the SEC has exempted as not comprehended within the purposes of section $16(b)$ acquisitions or dispositions of shares by shareholders of the disappearing corporation incident to a merger, consolidation, or assets-for-stock exchange where that corporation owned $85 \%$ or more of the stock of the surviving corporation prior to the merger or owned $85 \%$ or more of the total assets involved in the merger. A qualification, however, destroys the exemption where the insider makes both a purchase of shares of one corporation involved in the merger and a sale of the stock of another corporation involved in the merger within a 6 month period during which the merger has occurred.

113 Although no specific example of such a phenomenon can be shown, it is theoretically possible. It would most likely occur where the potential of coverage was so obvious that an insider with any knowledge of $\S 16(\mathrm{~b})$ would steer clear and where certainty as to coverage would be so great that any attorney, when asked, would 
The SEC should adopt a rule exempting certain acquisition transactions from the operation of section $16(\mathrm{~b})$. Such a rule should provide that no purchase or sale occurs for the purposes of section 16(b) when shares are exchanged pursuant to a plan or agreement for merger, ${ }^{114}$ where the terms of the plan or agreement are, with the exception of statutory appraisal rights, binding upon all stockholders. The rule should contain a proviso, however, that the exemption is inapplicable where there has been a purchase of $A$ stock and sale of $B$ stock or a sale of $A$ stock and purchase of $B$ stock within a period of six months which includes the consummation of the merger. ${ }^{115} A$ second proviso should also be included in such a rule. Where the original purchase of $A$ stock has occurred prior to the stockholder approval and public announcement of the consolidation, the exchange of such shares in connection with a merger should always constitute a "sale" for section 16(b) purposes if accomplished within six months of the original purchase.

always advise not to trade within 6 months. Whether such a transaction exists is open to speculation. The theoretical possibility that it does exist, however, is traceable to 2 real facts of the life of 16(b). First, a number of the cases which result in extended litigation were probably not designed for litigation, but were caused by mistakes. The possibility therefore exists that absent such mistakes some transactions may never be presented to a court to determine whether they lend themselves to $\$ 16$ (b) abuses. Second, the deterrent of $\$ 16(\mathrm{~b})$ may be so effective that insiders, even if they feel their transaction is not within the intent of $\$ 16(\mathrm{~b})$, may be unwilling to assume the financial costs and risks of litigation to prove their point.

114 Also includable should be a consolidation, reclassification, and an exchange of assets for securities of another corporation.

115 Cf. Rule 16b-7(c), 17 C.F.R. 240. 16b-7(c) (1968). 